\title{
Transcription of the Influenza Ribonucleic Acid Genome by a Virion Polymerase
}

\author{
III. Completeness of the Transcription Process
}

\author{
DAVID H. L. BISHOP, POLLY ROY, WILLIAM J. BEAN, JR., AND ROBERT W. SIMPSON \\ Institute of Microbiology, Rutgers University, The State University of New Jersey, \\ New Brunswick, New Jersey 08903
}

Received for publication 8 June 1972

\begin{abstract}
The virion ribonucleic acid (RNA) polymerase of influenza strain $A_{0} /$ WS transcribed at least $81 \%$ of the viral genome in vitro. The polymerase is shown to be associated with each of the major size classes of the virion RNA-ribonucleoprotein complexes. Under optimal in vitro conditions, at least $45 \%$ of the RNA contained in a population of influenza virions was involved in a repetitive transcription process. The detectable proteins associated with enzymatically active complexes containing RNA, ribonucleoprotein, and polymerase have been identified by polyacrylamide gel electrophoresis.
\end{abstract}

Influenza virus possesses a virion ribonucleic acid (RNA)-dependent RNA polymerase (10, 14, 20). In vitro assays have demonstrated that even closely related strains of influenza virus (e.g., WSN and WS) apparently possess different amounts of enzyme activity as judged by their rate of uridine monophosphate (UMP) incorporation per milligram of viral protein (10). We have previously examined the properties of the in vitro transcription process using the less active influenza WSN strain. This strain was chosen because it can be grown in tissue culture and the virion RNA can be labeled sufficiently with ${ }^{3} \mathrm{H}$ uridine to allow its fate to be monitored in product analysis experiments $(4,5)$. In such experiments, we demonstrated that in $2 \mathrm{hr}$ of in vitro incubation, about $7 \%$ of the virion RNA was involved in transcription and at least $14 \%$ of the genome was transcribed. Since most of the product RNA was initially associated with the virion ${ }^{3} \mathrm{H}-\mathrm{RNA}$ species and all of it could be annealed to the ${ }^{3} \mathrm{H}-\mathrm{RNA}$, these results suggested that the enzyme activity was responsible for transcribing some or all of the viral genome into complementary product RNA species.

In this communication, we have used the more active influenza WS strain and examined the amount of viral RNA involved in transcription, the extent of the transcription process, the association of the virion polymerase with the RNAribonucleoprotein complexes, and the protein species associated with these complexes. Which of these proteins constitute the virion polymerase is under study.

\section{MATERIALS AND METHODS}

Virus preparations. Influenza A virus, strain WS, was grown in the allantoic membrane of embryonated or de-embryonated chicken eggs by use of a modification of the technique of Bernkopf $(1$; Stevens and Simpson, in preparation). Each egg received $0.2 \mathrm{mCi}$ of ${ }^{3} \mathrm{H}$-uridine (specific activity, $22 \mathrm{mCi}$ per $\mu$ mole) and $1.4 \times 10^{5}$ to $140 \times 10^{5} \mathrm{egg}$ infectious units of virus. After incubation at $37 \mathrm{C}$ for $30 \mathrm{hr}$, the egg fluids were harvested and pooled. These pools, having hemagglutinin titers of $1: 4,096$, were then centrifuged at $7,500 \times g$ for $30 \mathrm{~min}$ at $4 \mathrm{C}$ to remove debris. Virus was obtained from the clarified supernatant fluid by precipitation with polyethylene glycol (Carbowax 6000 ) and was thereafter purified by a double-cushion centrifugation with the use of 30 and $60 \%(w / v)$ sucrose as described previously (9). Virus was harvested from the surface of the $60 \%$ sucrose layer, diluted with $0.15 \mathrm{M} \mathrm{NaCl}, 0.01 \mathrm{M}$ tris(bydroxymethyl)aminomethane (Tris)-hydrochloride buffer ( $p \mathbf{H}$ 7.4), and then centrifuged to equilibrium in a 20 to $70 \%$ (w/v) sucrose gradient prepared in $0.15 \mathrm{M} \mathrm{NaCl}, 0.01 \mathrm{M}$ Tris-hydrochloride buffer $(p \mathrm{H}$ 7.4). The centrifugation conditions were 25,000 rev/min in a Spinco SW27 rotor at $4 \mathrm{C}$ for $17 \mathrm{hr}$. Virus was collected from the gradient, and sucrose was removed by passage through a 10-ml column of Sephadex G25, equilibrated and eluted in $0.15 \mathrm{M} \mathrm{NaCl}, 0.01 \mathrm{M}$ Tris-hydrochloride buffer, $p \mathrm{H} \mathrm{7.4.} \mathrm{The} \mathrm{final} \mathrm{virus} \mathrm{preparations} \mathrm{contained}$ $0.8 \mathrm{mg}$ of protein per $\mathrm{ml}$ and possessed RNA specific activities of $2 \times 10^{3}$ or $2.5 \times 10^{4}$ counts $/ \mathrm{min}$ of ${ }^{3} \mathrm{H}$ per $\mu \mathrm{g}$ of RNA-the latter being derived from the WS-infected de-embryonated eggs.

Enzyme assays and purification of the reaction product nucleic acids. Reaction mixtures were prepared containing ${ }^{32} \mathrm{P}-\alpha$-uridine triphosphate (UTP) to label the product species as described previously $(4,5)$. In 
the experiment designed to determine the extent of the transcription process with WS virus of lower ${ }^{3} \mathrm{H}-\mathrm{RNA}$ specific activity, the specific activity of the ${ }^{32}$ P-UTP was 8 counts per min per pmole (i.e., approximately 6,000 counts per min per $\mu \mathrm{g}$ of product RNA, assuming 25 mole \% of UMP in the product). In other experiments, the UTP specific activity was 5,300 counts per min per pmole. Reaction product nucleic acids were purified from protein and triphosphates, etc., as described previously (6).

Annealing of reaction product nucleic acids and RNA polyacrylamide gel electrophoresis. Procedures have been described for annealing reaction product nucleic acids and determining the ribonuclease resistance of the annealed RNA (5). The separation of RNA species by gel electrophoresis in swollen $3.2 \%$ polyacrylamide gels by use of Tris-acetate buffer $(p \mathrm{H}$ 7.4) containing $0.1 \%$ sodium dodecyl sulfate (SDS) has also been described $(3,7)$. After electrophoresis, the gels were sliced, and the distribution of RNA species was determined by dissolving the slices in $30 \%(\mathrm{v} / \mathrm{v}) \mathrm{H}_{2} \mathrm{O}_{2}$ and counting in a liquid scintillation counter with Aquasol (New England Nuclear Corp., Boston, Mass.).

Isolation of influenza virion RNA-ribonucleoprotein complexes. The procedure used to isolate the virion RNA-ribonucleoprotein complexes of influenza was a modification of that described by Pons (15). A preparation of virus in $1 \mathrm{ml}$ of $0.15 \mathrm{M} \mathrm{NaCl}, 0.01 \mathrm{M}$ Tris-

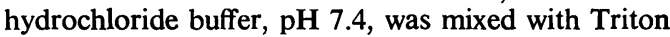
N101, sodium deoxycholate (DOC), urea, and mercaptoethanol (at final concentrations of $3 \mathrm{mg} / \mathrm{ml}$, $0.1 \%, 0.2 \mathrm{M}$, and $0.01 \mathrm{M}$, respectively), and was then incubated at $31 \mathrm{C}$ for $5 \mathrm{~min}$; by this procedure, the virus suspension completely lost its turbid appearance. Incubation at 4 or $20 \mathrm{C}$ was insufficient to achieve release of the RNA-ribonucleoprotein complexes from the virions. The mixture was cooled to $4 \mathrm{C}$ and loaded over a $10.5-\mathrm{ml}$ linear gradient of 15 to $30 \%(\mathrm{w} / \mathrm{v})$ sucrose in $0.15 \mathrm{M} \mathrm{NaCl}, 0.01 \mathrm{M}$ Tris-hydrochloride buffer ( $p \mathrm{H} 7.5), 0.01 \mathrm{~m}$ mercaptoethanol, $0.2 \mathrm{M}$ urea, $0.02 \%$ DOC, and $3 \mathrm{mg}$ of Triton N101 per ml, prepared and held at $3 \mathrm{C}$ in a Spinco SW41 tube over a $0.5-\mathrm{ml}$ cushion of $70 \%(\mathrm{w} / \mathrm{v})$ sucrose. The gradient was centrifuged at $40,000 \mathrm{rev} / \mathrm{min}$ at $3 \mathrm{C}$ for $4 \mathrm{hr}$. Each fraction of the gradient was assayed for content of ${ }^{3} \mathrm{H}-\mathrm{RNA}$ and RNA polymerase activity (4) with or without added influenza RNA $(0.5 \mu \mathrm{g}$ per $125-\mu$ liter reaction mixture), and the indicated fractions were pooled to determine their content of protein or RNA by polyacrylamide gel electrophoresis.

The conditions employed for dissociating virus were selected solely with reference to their effect on the virion transcriptase activity. For example, the rate of enzyme activity was determined in reactions containing increasing concentrations of Triton N101. Maximal enzyme activity was obtained in the presence of 1 to $10 \mathrm{mg}$ of Triton $\mathrm{N} 101$ per $\mathrm{ml}$ of reaction mixture. In the presence of $3 \mathrm{mg}$ of Triton N101 per $\mathrm{ml}$ of virus preparation, pretreatment of the virus at $31 \mathrm{C}$ for 5 min with DOC ( $p \mathrm{H} \mathrm{7.8)}$ was examined. After pretreatment, the virus was diluted fivefold into the reaction mixture, and the rate of enzyme activity was again determined. It was found that pretreatment with greater than $1 \%$ deoxycholate was totally inhibitory for polymerase function. Pretreatment with $0.1,0.3$, and $0.6 \%$ DOC inhibited the enzyme activity by 16 , 60 , and $82 \%$, respectively. With $3 \mathrm{mg}$ of Triton N101 per $\mathrm{ml}$, inclusion of urea in the reaction mixture was also examined. It was found that reaction concentrations of urea of greater than $1 \mathrm{M}$ were totally inhibitory. Reaction concentrations of $0.1,0.3$, and $0.5 \mathrm{M}$ urea depressed the rate of enzyme activity by 15,40 , and $70 \%$, respectively. Pretreatment of virus with Triton N101 (3 mg per $\mathrm{ml}$ ) and DOC (0.1\%) and dilution into a reaction mixture containing $0.2 \mathrm{M}$ urea depressed the enzyme activity by $30 \%$ in comparison to a Triton-treated virus preparation. The enzyme activity, however, was linear for only $1 \mathrm{hr}$ after these treatments, in contrast to Triton-treated virus whose enzyme activity is linear for 6 to $8 \mathrm{hr}$. The reason for this inhibition is not known. Inclusion of mercaptoethanol ( $0.01 \mathrm{M}$ final concentration) did not inhibit the reaction rate. From these preliminary experiments, the conditions for pretreating virus were devised.

Separation of influenza proteins by SDS polyacrylamide gel electrophoresis. Virus or subviral components were precipitated with $5 \%(\mathrm{w} / \mathrm{v})$ trichloroacetic acid and held at $4 \mathrm{C}$ for a minimum of $4 \mathrm{hr}$; the precipitate was collected by centrifugation at $4 \mathrm{C}$ and 20,000 $\times g$ for 30 min by use of a Sorvall swinging-bucket HB4 rotor and a Spinco SW41 centrifuge tube. The precipitate was washed by centrifugation with $5 \%$ trichloroacetic acid, followed by two washes with absolute alcohol to remove the detergents and acid. After drying, the pellets were dissociated in 50 to 200

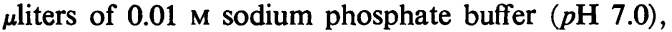
$0.1 \%$ SDS, $1 \mathrm{~m}$ urea, and $0.01 \mathrm{M}$ dithiothreitol for 30 min at $60 \mathrm{C}$; they were then mixed with $20 \mu$ liters of glycerol and subjected to electrophoresis in $8 \%$ polyacrylamide gels as described previously (8). The gels were stained by Coomassie brilliant blue, and the stained proteins were scanned at $640 \mathrm{~mm}$ with an automatic double-beam spectrodensitometer (model SD3000, Schoeffel Instrument Corp., Westwood, N.J.). The main protein bands were identified by comparison with parallel electropherograms of SDS-disrupted virus.

\section{RESULTS}

Extent of transcription by influenza WS virion transcriptase. In incubations with WSN virus, we have obtained by $2 \mathrm{hr}$ of incubation at least $14 \%$ transcription of the virion genome in a transcription process in which at least $7 \%$ of the viral RNA was involved (5). Since the linear incorporation of triphosphates ceased between 6 and $7 \mathrm{hr}$ of incubation, in those in vitro reactions, we have not been able to obtain more than $28 \%$ transcription involving $18 \%$ of the viral RNA. We have not been able to determine with WSN whether this incomplete transcription was due to an inherent property of the transcription process or was caused by the in vitro conditions to which the virus was exposed. However, we have found that product RNA is associated with the five major classes of virion RNA (containing seven 
RNA species) suggestive of a transcription process associated with each virion RNA molecule (5). In the present dissertation, we report the extent of transcription by the egg-grown influenza strain $A_{0} / W S$ virus which has been shown to contain a more active polymerase (10).

A reaction mixture containing ${ }^{32} \mathrm{P}-\alpha$-UTP to label product RNA was incubated at $31 \mathrm{C}$ with ${ }^{3} \mathrm{H}$-uridine-labeled WS virus grown in embryonated eggs. Samples were withdrawn at intervals, and the reaction product RNA (consisting of ${ }^{32} \mathrm{P}$-product and ${ }^{3} \mathrm{H}$-virion species) was purified. The ribonuclease resistance of the reaction product nucleic acids was determined before and after an annealing pretreatment (Fig. 1). It was found that through $8 \mathrm{hr}$ of reaction incubation the ribonuclease resistance of the virion ${ }^{3} \mathrm{H}-\mathrm{RNA}$ increased from $0.5 \%$ for the zero-time unincubated sample to 40 and $47 \%$ for the 6- and 8-hr samples, respectively. This result indicated that in this population of WS viral particles at least 40 to $50 \%$ of the virion RNA was involved in the transcription process.

The ribonuclease resistance of the annealed ${ }^{3} \mathrm{H}-\mathrm{RNA}$ increased from $3 \%$ for the zero-time sample to 62 and $81 \%$ for the 6-and 8-hr samples, respectively, indicating that at least $80 \%$ of the virion RNA had been transcribed. Since, however, only 40 to $50 \%$ of the viral RNA population became ribonuclease-resistant as a result of transcription, these results suggest either that 40 to $50 \%$ of the virions possessed active enzyme whose transcription process was repetitive and at least $80 \%$ complete, or that $81 \%$ of the virion RNA population was involved in transcription.

The ribonuclease resistance of the ${ }^{32} \mathrm{P}$-product RNA species was $70 \%$ for the unannealed $1-\mathrm{hr}$ sample and $42 \%$ for the unannealed 8 -hr sample. After annealing, the ribonuclease resistance of the product species increased to 98 and $70 \%$ for the same two samples, respectively. When more WS viral RNA was added to the 8-hr sample (6 $\mu \mathrm{g}$ per $\mathrm{ml}$ per annealing mixture), the ribonuclease resistance of the annealed product species increased to $97 \%$, indicating that most of the 8 -hr product RNA was complementary to the virion genome rather than identical in sequence to the viral RNA. Since the $27 \%$ increase in the ribonuclease resistance of the $8-\mathrm{hr}{ }^{32} \mathrm{P}$ product RNA was obtained only after addition of WS viral RNA, this result indicated that the transcription process was indeed repetitive.

Dissociation of influenza WS and separation of the virion RNA-ribonucleoprotein complexes. A useful procedure has been developed for the dissociation of influenza strain $\mathrm{A}_{0} / \mathrm{WSN}$ and isolation of the virion RNA-ribonucleoprotein complexes (15). We have confirmed these obser-
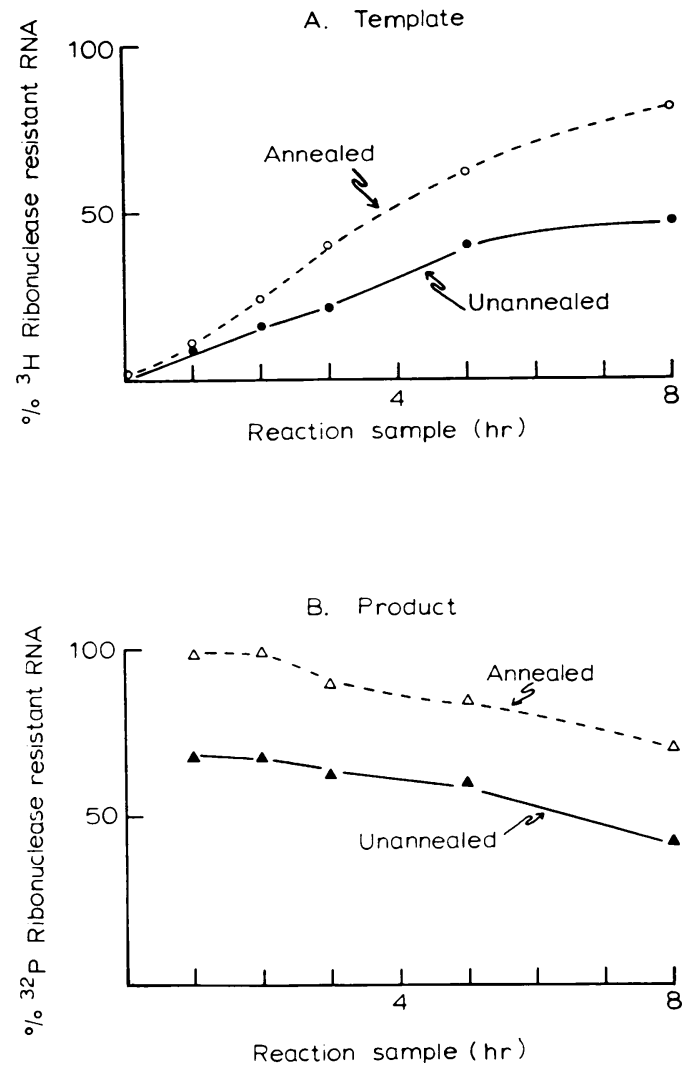

FIG. 1. Extent of transcription by influenza WS virion polymerase. A 50-fold standard influenza WS polymerase reaction $6.25 \mathrm{ml}$ (4) containing $\alpha^{-32} P$-UTP (8 counts per min per pmole) to label the product species and ${ }^{3} \mathrm{H}$ uridine-labeled virus $\left(2 \times 10^{3}\right.$ counts per min per $\mu g$ of $R N A)$ was incubated at $31 \mathrm{C}$ through $8 \mathrm{hr}$. Samples were withdrawn at intervals, and the reaction product nucleic acids were purified from protein and triphosphates, etc. (6). Each RNA sample was suspended in 150 uliters of $0.01 \mathrm{M}$ sodium phosphate buffers, $0.005 \mathrm{M}$ ethylenediaminetetraacetate ( $p H 7.0)$, giving a ${ }^{3} H-R N A$ concentration of about $3 \mu \mathrm{g} \mathrm{per} \mathrm{ml}$, and a portion (40 uliters) was annealed at $65 \mathrm{C}$ for $4 \mathrm{hr}$ in the presence of $0.4 \mathrm{M} \mathrm{NaCl}$. Another portion, also in $0.4 \mathrm{M} \mathrm{NaCl}$, was held at $4 \mathrm{C}$ for $4 \mathrm{hr}$. Both portions were then diluted into $2.1 \mathrm{ml}$ of $0.4 \mathrm{M} \mathrm{NaCl}, 0.01 \mathrm{M}$ Tris-hydrochloride buffer, pH 3.4, and $1 \mathrm{ml}$ was subtracted to determine the trichloroacetic acid-insoluble radioactivity. $A$ second 1 $\mathrm{ml}$ was treated with ribonuclease $A$ and $T_{1}$ (10 $\mu \mathrm{g}$ each) at $37 \mathrm{C}$ for $30 \mathrm{~min}$ before determining the residual trichloroacetic acid-insoluble radioactivity. The percent ribonuclease-resistant template $\left({ }^{3} \mathrm{H}\right) \mathrm{RNA}$ or product ( ${ }^{32} P$ ) $R N A$ of the annealed or unannealed samples is given. A ribonuclease resistance of $100 \%$ was equivalent to about 240 counts per min of ${ }^{3} \mathrm{H}-\mathrm{RN} A$ per annealing mixture and $0,520,860,1,080,1,150$ and 1,560 counts per min of ${ }^{32} P-R N A$ per annealing mixture for the 0 -, 1-, 2-, 3-, 5-, and 8-hr samples, respectively. 

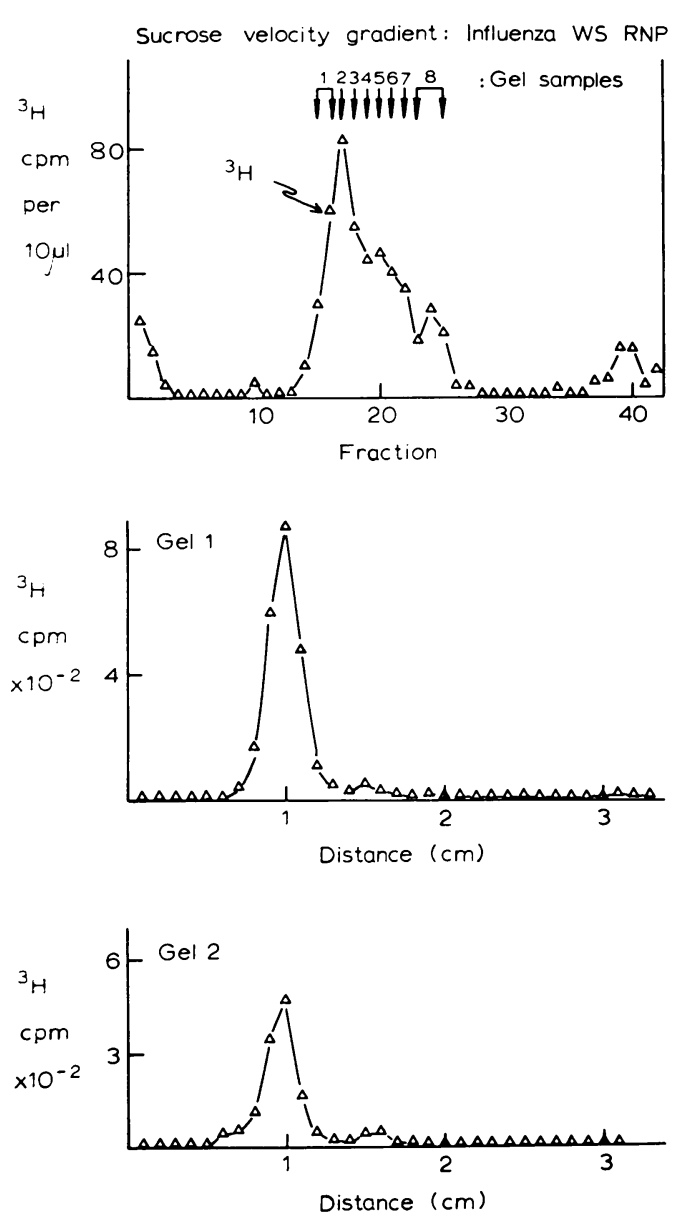

FIG. 2. Dissociation of influenza WS and separation of the virion $R N A$-ribonucleoprotein complexes. $A 1-m l$ preparation of ${ }^{3} \mathrm{H}$-uridine-labeled influenza $W S$ virus $\left(2.5 \times 10^{4}\right.$ counts per min of ${ }^{3} \mathrm{H} \mu \mathrm{g}$ of $\left.\mathrm{RNA}\right)$ in $0.15 \mathrm{M}$ $\mathrm{NaCl}, 0.01$ M Tris-hydrochloride buffer, $\mathrm{pH} \mathrm{3.4, \text {was }}$ dissociated by Triton N101, DOC, urea, and mercaptoethanol at $31 \mathrm{C}$ for 5 min as described in Materials and Methods, and then was cooled to $4 C$ in an ice bath. The dissociated virus, which visually was completely clear, was then loaded on a $10.5-\mathrm{ml}$ linear gradient of 15 to $30 \%$ sucrose containing $0.15 \mathrm{M} \mathrm{NaCl}, 0.01 \mathrm{M}$ Trishydrochloride buffer ( $p H$ 7.5), $0.01 \mathrm{M}$ mercaptoethanol, $0.2 \mathrm{M}$ urea, $0.02 \% \mathrm{DOC}$, and $3 \mathrm{mg}$ of Triton $N 101 \mathrm{per}$ $m l$ in a Spinco SW4I centrifuge tube. The gradient, which was made over a $0.5-\mathrm{ml}$ cushion of $70 \%(w / v)$ sucrose, was centrifuged at 40,000 rev/min at $3 \mathrm{C}$ for 4 $\mathrm{hr}$. The distribution of ${ }^{3} \mathrm{H}-\mathrm{RNA}$ was determined on samples of each fraction, and the indicated fractions were pooled, mixed with sodium dodecyl sulfate, and subjected to polyacrylamide gel electrophoresis to resolve the RNA species. The electrophoretic conditions are described in the text. After electrophoresis, the gels were sliced and dissolved in $\mathrm{H}_{2} \mathrm{O}_{2}$ as described previously $(3,5,7)$; the distribution of ${ }^{3} H-R N A$ was determined by use of Aquasol. The sucrose gradient profile of the dissociated ${ }^{3} \mathrm{H}-W \mathrm{~W}$ virus is shown in the first panel. Subsequent panels show the eight RNA gel electropherograms of the indicated gradient fractions.
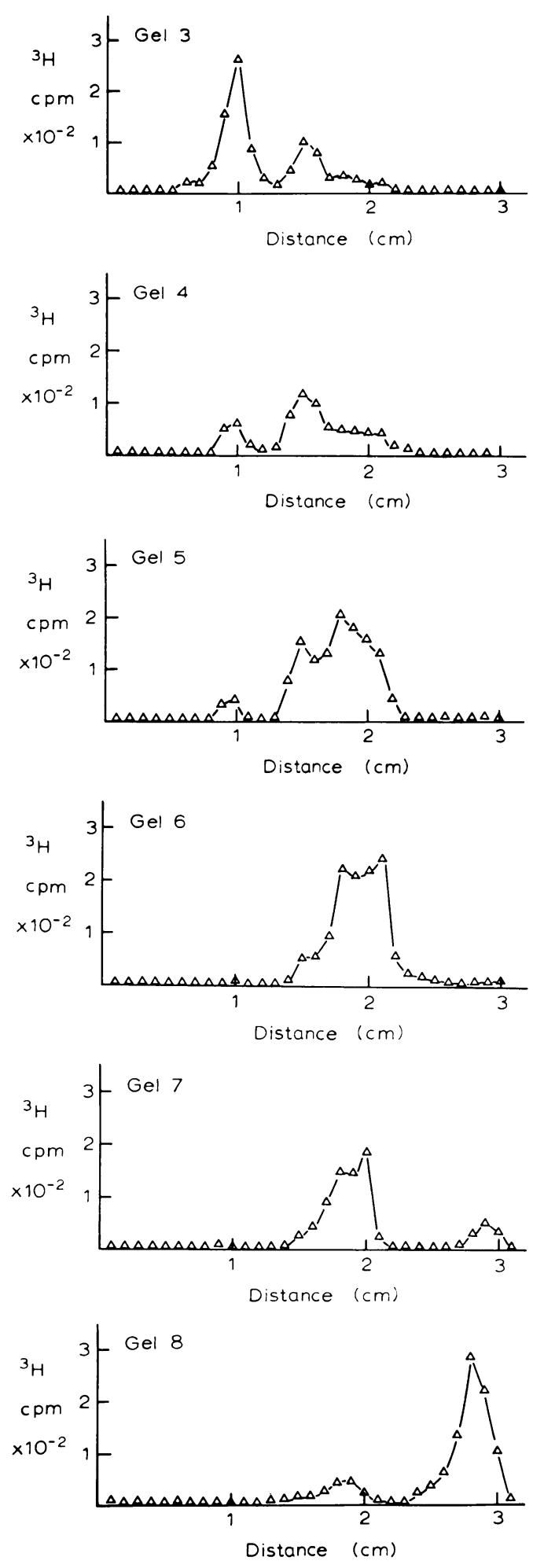
vations and applied the procedure to answer the question of whether these complexes have enzyme activity and, if so, which of the virion proteins are present in these structures. A preparation of ${ }^{3} \mathrm{H}$-labeled virus was dissociated by Triton N101, DOC, and urea, and the products were resolved by velocity centrifugation in a gradient of sucrose as described in Materials and Methods. Each fraction was monitored for labeled RNA (Fig. 2); the indicated fractions were pooled and dissociated with SDS, and their content of RNA was determined by polyacrylamide gel electrophoresis (Fig. 2). The electrophoretic conditions were adapted to overcome the problems engendered by the high ionic content of the samples, as well as their large loading volumes $(0.1$ to $0.3 \mathrm{ml})$, by running the gels in the presence of $3 \mathrm{E}$ buffer (i.e.,

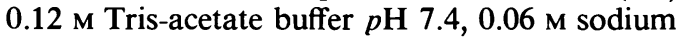
acetate; see reference 7). Very little label was recovered on the $70 \%$ sucrose cushion or in the top fractions of the gradient, indicating that most of the virus had been dissociated and that most of the label was present in the virion RNA-ribonucleoprotein complexes (see below). Examination of the gel electropherograms revealed that sucrose gradient fractions 14 to 16 principally contained the large class of viral RNA species (compare with Fig. 3, which shows the RNA gel electropherogram of the complete virus preparation). Fractions 23 to 25 principally contained the smallest class of virion RNA species. The intermediate fractions contained various mixtures of the five classes of virion RNA molecules as shown in Fig. 2. These results suggest, therefore, that the conditions chosen for dissociation of WS influenza virus were adequate, but the separation between various virion ribonucleoprotein complexes was not very good.

Association of polymerase and proteins with influenza RNA-ribonucleoprotein complexes. A preparation of ${ }^{3} \mathrm{H}$-labeled influenza WS was dissociated with Triton N101, DOC, and urea, and the RNA-ribonucleoprotein complexes were resolved by sucrose gradient velocity centrifugation as described in the previous section. Each fraction of the gradient was assayed for RNA polymerase activity in the presence or absence (endogenous activity) of added influenza RNA (Fig. 4). The majority of the endogenous polymerase activity was recovered in those fractions which contained the ${ }^{3} \mathrm{H}-\mathrm{RNA}$-ribonucleoprotein complexes. Addition of influenza RNA only slightly enhanced the enzyme activity of some of these fractions. There was also some templated enzyme activity at the top of the gradient.

The indicated fractions were pooled and precipitated with $5 \%$ trichloroacetic acid; the pre-

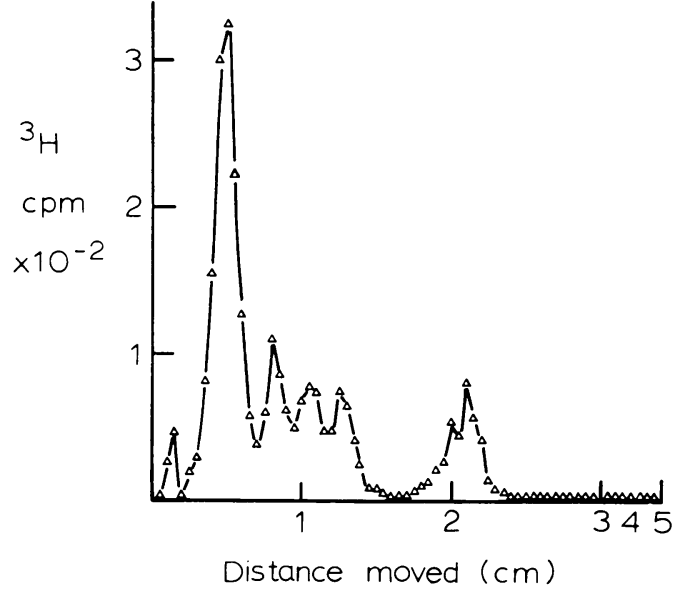

FIG. 3. RNA electropherogram of influenza WS. A sample of ${ }^{3} \mathrm{H}$-uridine-labeled influenza $W S$ virus $(2.5 \times$ $10^{4}$ counts per min of ${ }^{3} \mathrm{H}$ per $\mu \mathrm{g}$ of $\mathrm{RNA}$ ) was mixed with SDS (1\% final concentration) and subjected to electrophoresis in swollen $3.2 \%$ polyacrylamide gels as described previously (5). The distribution of ${ }^{3} \mathrm{H}-\mathrm{RNA}$ was determined after the gel was sliced and dissolved by $\mathrm{H}_{2} \mathrm{O}_{2}$.

cipitate was collected by centrifugation. After dissociation in SDS (see Materials and Methods), protein gel electrophoresis was performed on each sample (Fig. 5). By comparison with the protein electropherogram of complete virus, it was determined that the virion ribonucleoprotein, NP, and the two minor proteins, $P$, were present in the gradient fractions which also contained the labeled RNA and endogenous polymerase activity (i.e., gradient pools 3 and 4, Fig. 4). Although the resolution between NP and HA1 and NA (the glycoproteins hemagglutinin subunit 1 and neuraminidase, respectively) was poor, these latter two proteins were apparently absent from the gradient fractions which contained the labeled RNA and endogenous enzyme activity (see Discussion and legend to Fig. 5). The top fractions of the gradient (i.e., gradient pools 6 and 7, Fig. 4) apparently contained all the glycoproteins as well as the membrane (M) protein (see Discussion). From these results, it was concluded that the RNA-ribonuceloprotein complexes of influenza virus contain RNA, polymerase, and probably only the major virion protein NP and minor proteins P. As can be seen from Fig. 5, most of the virion ribonucleoprotein was recovered in the fractions which also contained the RNA and transcriptase enzyme activity. Procedures to dissociate proteins from these complexes are currently being investigated. 

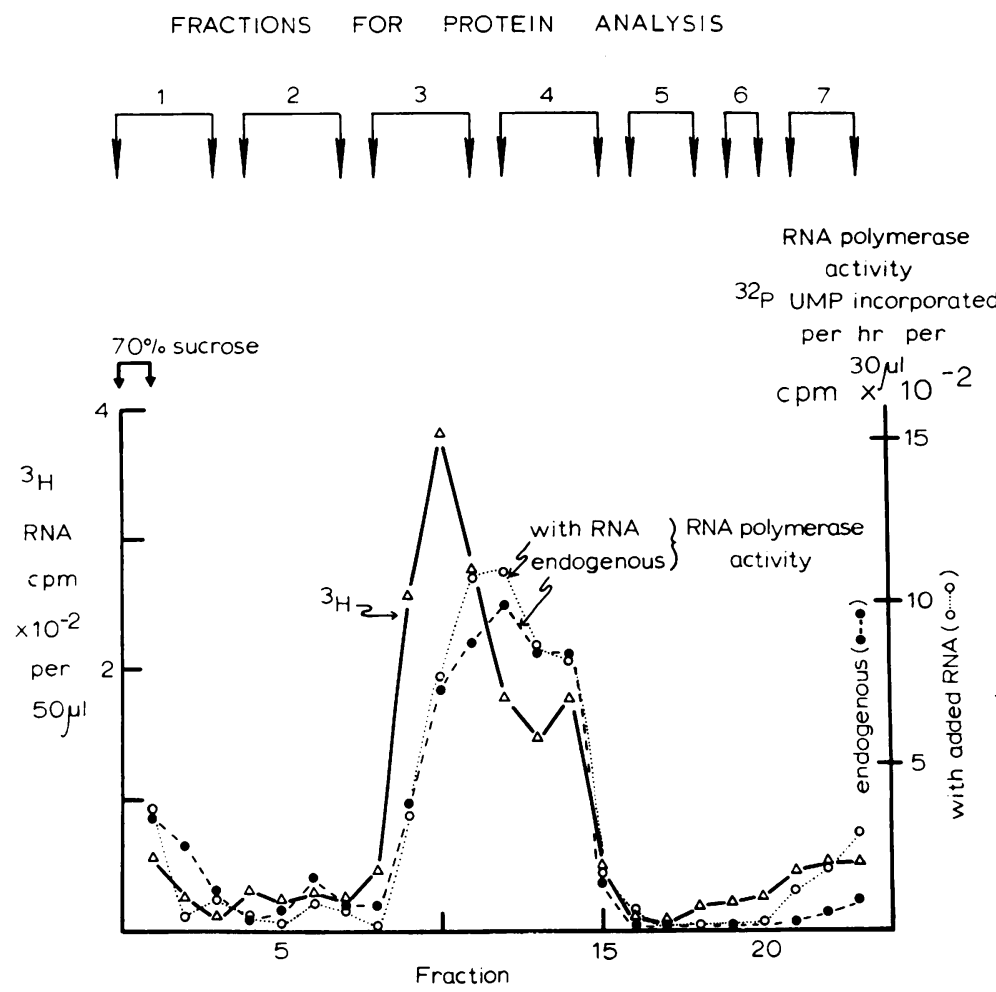

FIG. 4. Association of polymerase and proteins with influenza RNA-ribonucleoprotein complexes. A 1-ml preparation of ${ }^{3} \mathrm{H}$-uridine-labeled influenza WS virus $\left(2.5 \times 10^{4}\right.$ counts per min of ${ }^{3} \mathrm{H}$ per $\mu \mathrm{g}$ of $\left.\mathrm{RNA}\right)$ was dissociated by Triton N101, DOC, urea, and mercaptoethanol as described in Materials and Methods, and the virion RNAribonucleoprotein complexes were resolved by sucrose gradient velocity centrifugation (see Materials and Methods and Fig. 2). Samples of each fraction were taken to determine the distribution of ${ }^{3} H-R N A$ and $R N A$ polymerase activity as described in the text. The enzyme activity (endogenous or with the addition of influenza RNA; see Materials and Methods) is expressed as the counts per minute of ${ }^{32} \mathrm{P}-\mathrm{UMP}$ incorporated during $1 \mathrm{hr}$ of incubation at 31 C, after subtracting the "background" value of an unincubated mixture (zero time: about 200 counts/ min of ${ }^{32} P$ ). The indicated fractions were pooled for subsequent protein analyses (Fig. 5).

\section{DISCUSSION}

Transcription process of influenza viruses. It has been shown that influenza WS virion transcriptase is able to transcribe at least $80 \%$ of the viral genome. The process is repetitive and probably involves all classes of the segmented viral RNA genome. As we have previously shown, the products of the transcription process consist only of complementary RNA (5); therefore, these results suggest that the product RNA species probably have some important function in the infection process of a cell by influenza virus. Such a proposal has been substantiated by the recent finding that polysomal messenger RNA species in influenza-infected cells is complementary to the virion genome (16). Consequently, it would appear that the virion transcriptase is responsible for the synthesis of influenza messenger RNA species. In vitro, the transcription process is slow, even with the relatively active WS virion transcriptase. For the WSN strain, the in vitro process appears even slower, although it is not known whether this relates to the possession of a different polymerase or reflects the lower number of virions in a population of particles exhibiting enzyme activity. To obtain an answer to these possibilities will require obtaining genome recombinants between the two viruses and an examination of the rate of product synthesis as well as the amount of virion RNA involved in transcription; this is currently being undertaken.

Association of transcriptase with the RNA-ribonucleoprotein complexes. When influenza virus is dissociated by appropriate techniques, the virion RNA-ribonucleoprotein complexes can be partially separated from each other by sucrose gradient velocity centrifugation. Since separation of the complexes can be obtained in this manner, these results indicate that the virion complexes 

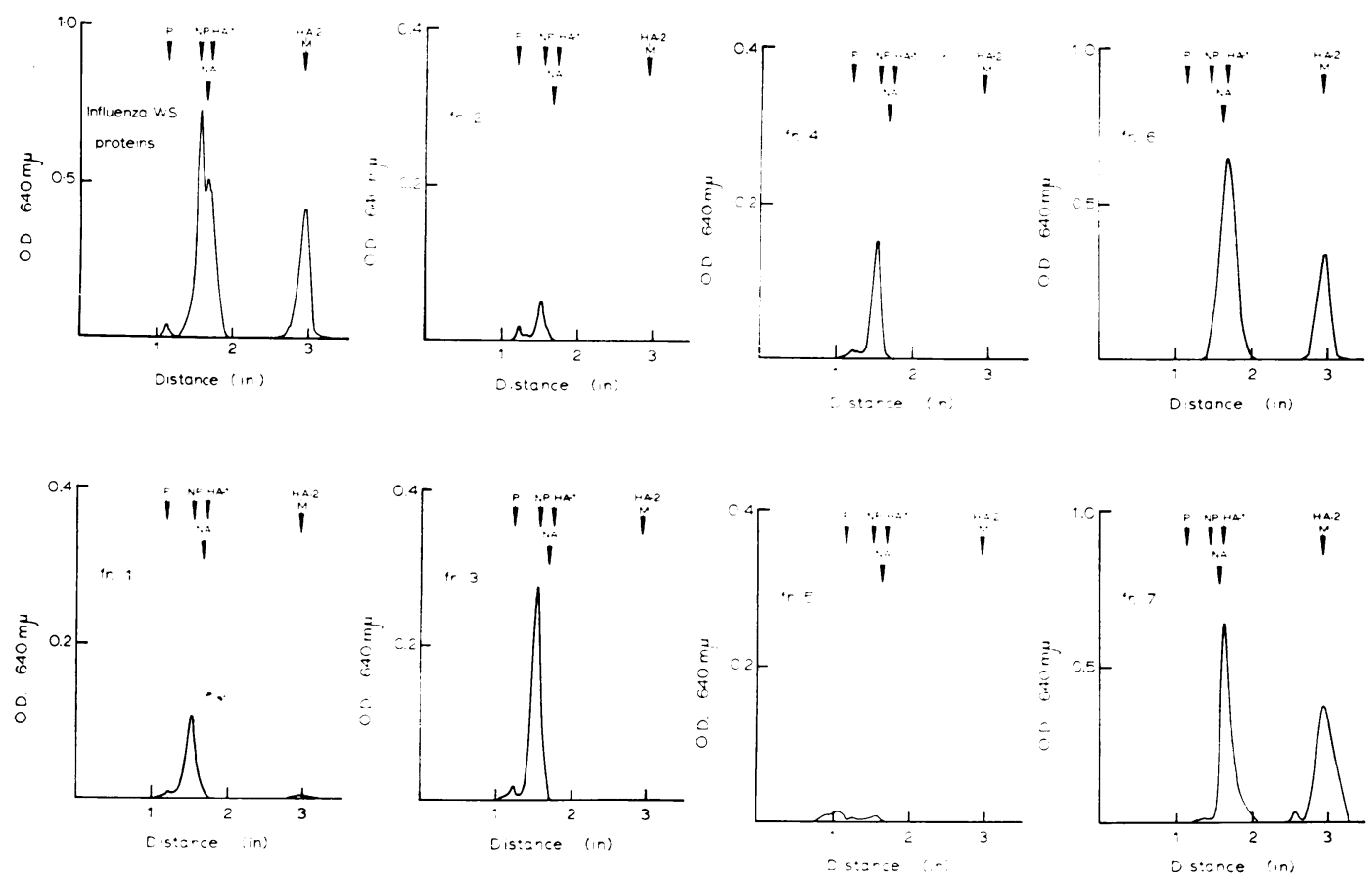

FIG. 5. Protein gel electrophoresis of influenza WS and its dissociated components. The gradient pools from Fig. 4 were mixed in an SW41 centrifuge tube with trichloroacetic acid (5\% final concentration) and kept at 4 C for $4 \mathrm{hr}$. The precipitated proteins were collected by centrifugation at $4 \mathrm{C}$ and $20,000 \times \mathrm{g}$, and were washed once with $5 \%$ trichloroacetic acid and then twice with absolute ethanol to remove trichloroacetic acid and the detergents. After drying, the proteins were dissociated and resolved by gel electrophoresis, and the stained proteins were scanned at $640 \mathrm{~nm}$ (see Materials and Methods). The proteins of complete influenza WS virus, run in parallel, are also shown. The influenza proteins were identified from the data of Compans et al. (11) and Schulze (18), and are named in accordance with the decision of the influenza workshop held in Madison, Wis., in 1971 (19). The influenza hemagglutinin glycoprotein HA1:HA2 was completely dissociated under the conditions used, and the subunits were recovered as indicated. The other glycoprotein, neuraminidase $(N A)$, could not be identified, but its presumed position is also indicated (see 11, 18, 21). The two major non-carbohydrate-containing virion proteins, nucleoprotein (NP) and membrane protein $(M)$, were clearly seen as indicated, although the former (the sharp NP band) runs close to the two diffuse glycoproteins $(\mathrm{HAl}$ and NA). Owing to the small amounts of protein in the samples, the whole sample of each pool was loaded on the gels except for gradient pools 3 and 4 , of which only one-third of the protein was loaded. No stained protein was observed in gradient pool 5 despite the scan obtained, and this was probably because of irregularities.

are either separate from each other or linked through hydrogen-bonding or possibly disulfide bridges between their proteins in the virus particle. It is not known whether the complexes are also linked to other structural components of the virus, e.g., the membrane. We have demonstrated that most of the recovered endogenous RNA polymerase activity is associated with those gradient fractions which contain the ${ }^{3} \mathrm{H}-\mathrm{RNA}$-ribonucleoprotein complexes. We have obtained similar results, but with somewhat better separation, using influenza WSN strain (unpublished data).

It is of particular interest to note that the profiles of ${ }^{3} \mathrm{H}-\mathrm{RNA}$ and RNA polymerase activity of the dissociated virus spread by sucrose gradient centrifugation are not coincident (Fig. 4). We have obtained similar noncoincident profiles with influenza WSN virus. However, it should be remembered that the ${ }^{3} \mathrm{H}-\mathrm{RNA}$ in each fraction reflects the mass of RNA species present and not their molar ratio. Since the influenza RNA segments vary in molecular weight (from $1.05 \times 10^{6}$ to $\left.3.5 \times 10^{5}[5]\right)$, this means that per unit of ${ }^{3} \mathrm{H}$ counts per minute there can be a threefold variation in the number of RNA molecules between the fastest and slowest sedimenting RNAribonucleoprotein complexes. The number of active polymerase molecules per gradient fraction could possibly be related either to the RNA species mass or to their molar concentration. In the latter case, if all of the complexes have a similar number of active enzyme molecules asso- 
ciated with them, then one would expect to have less enzyme activity on a ${ }^{3} H-R N A$ mass basis in the leading fractions. Such is the observation in the results presented in Fig. 4, where it is apparent that the variation in enzyme activity across the RNA-ribonucleoprotein complexes profile is in the range predicted by these arguments. However, this result does not preclude the possibility that one or more of the RNA species do not have associated transcriptase enzyme. A conclusive decision on this point will have to await better resolution of the various complexes.

Proteins associated with the RNA-ribonucleoprotein complexes of influenza virus. The identification of the influenza virion proteins (Fig. 5) has been made by reference to the published protein electropherograms of influenza $A_{0}$ virus (11, $18,19)$, with the use of the nomenclature adopted at the influenza workshop held at Madison, Wis., in 1971. Under the conditions of dissociation we have used, the hemagglutinin complex (HA1: HA2) has been completely dissociated into its subunits HA1 and HA2 $(11,18,21)$.

We have not been able to identify or differentiate the two glycoproteins, hemagglutinin (HA1 subunit) and neuraminidase, or to separate the faster-moving hemagglutinin (HA2 subunit) and membrane protein (see 11,18 ). However, it is clear from the data presented in Fig. 5 that neither of the latter two proteins was present in those gradient fractions (fractions 3 and 4, Fig. 4 and 5) which contained the RNA-ribonucleoprotein complexes. It can also be concluded that the majority of the HA1 subunit and neuraminidase were also absent from those fractions and that they were recovered in the top gradient fractions which also contained the HA2 and membrane protein.

In unpublished similar experiments involving ${ }^{3} \mathrm{H}$-glucosamine-labeled WS virus (grown in de-embryonated eggs), we have observed that $99.7 \%$ of the viral ${ }^{3} \mathrm{H}$ label is recovered in the top gradient fractions after dissociation by the procedure we have described. Less than $0.3 \%$ of the ${ }^{3} \mathrm{H}$ label was recovered in the region which contained the RNA-ribonucleoprotein complexes. We are therefore led to conclude that neither the glycoproteins (NA, HA1, and HA2) nor the virion membrane protein $(\mathrm{M})$ are part of the RNA-ribonucleoprotein complexes.

The virion minor protein $P$, which can sometimes be seen as two barely separated bands (P1 and P2), was found in the same gradient fractions which contained the nucleoprotein NP, the RNA, and polymerase enzyme activity (gradient pools 3 and 4, Fig. 4 and 5). Not all of the $P$ protein was recovered in these fractions; some was apparently also recovered in the top fractions of the gradient and also on the $70 \%$ sucrose pad (see Fig. 5 legend). The relationship of the $\mathbf{P}$ proteins to the NP protein and polymerase is currently under investigation. Methods to dissociate the polymerase from the virion RNA and obtain active enzymes are also being investigated.

Other investigations into the protein composition of the ribonucleoprotein complexes of influenza and other viruses have not been conducted in relation to the retention of transcriptase enzyme activity $(2,12,13,17)$. Since in those reports only one protein was identified (NP), this could be due either to the different conditions employed for virion dissociation (e.g., high DOC concentration) or to the small amount of $P$ proteins associated with these complexes.

\section{ACKNOWLEDGMENTS}

This investigation was supported by Public Health Service grants AI-10692 and AI-09124 from the National Institute of Allergy and Infectious Diseases, by the Damon Runyon Memorial Fund grant DR 1169, and by Research Contract NIH-NCI 71-2077 from the National Cancer Institute. W. J. Bean is a predoctoral trainee under grant AI-09124 from the National Institute of Allergy and Infectious Diseases.

We thank Roger Van Deroef, Rebecca M. Shamy, Constance B. Cannata, and Christine L. Meyers for expert technical assistance.

\section{LITERATURE CITED}

1. Bernkopf, H. 1949. Cultivation of influenza virus in the chorioallantoic membrane of de-embryonated eggs. Proc. Soc. Exp. Biol. Med. 72:680-682.

2. Bikel, I., and P. H. Duesbers. 1969. Proteins of Newcasıle disease virus and of the viral nucleocapsid. J. Virol. 4:388-393.

3. Bishop, D. H. L., J. R. Claybrook, and S. Spiegelman. 1967. Electrophoretic separation of viral nucleic acids on polyacrylamide gels. J. Mol. Biol. 26:373-387.

4. Bishop, D. H. L., J. F. Obijeski, and R. W. Simpson. 1971. Transcription of the influenza ribonucleic acid genome by a virion polymerase. I. Optimal conditions for in vitro activity of the ribonucleic acid-dependent ribonucleic acid polymerase. J. Virol. 8:66-73.

5. Bishop, D. H. L., J. F. Obijeski, and R. W. Simpson. 1971. Transcription of the influenza ribonucleic acid genome by a virion polymerase. II. Nature of the in vitro polymerase product. J. Virol. 8:74-80.

6. Bishop, D. H. L., and P. Roy. 1971 . Kinetics of RNA synthesis by vesicular stomatitis virus particles. J. Mol. Biol. 57: 513-527.

7. Bishop, D. H. L., and P. Roy. 1971. The properties of the product synthesized by VSV particles. J. Mol. Biol. 55: 799-814.

8. Bishop, D. H. L., and P. Roy. 1972. Dissociation of vesicular stomatitis virus and relation of the virion proteins to the viral transcriptase. J. Virol. 10:234-243.

9. Bishop, D. H. L., R. Ruprecht, R. W. Simpson, and S. Spiegelman. 1971. Deoxyribonucleic acid polymerase of Rous sarcoma virus: reaction conditions and analysis of the reaction product nucleic acids. J. Virol. 8:730-741.

10. Chow, N., and R. W. Simpson. 1971. RNA-dependent RNA polymerase activity associated with virions and subviral components of myxoviruses. Proc. Nat. Acad. Sci. U.S.A. 68:752-756.

11. Compans, R. W., H. D. Klenk, L. A. Caliguri, and P. W. Choppin. 1971. Analysis of polypeptides of the virion and identification of spike glycoproteins. Virology 42:880-889.

12. Content, J., and P. H. Duesberg. 1970. Electrophoretic dis- 
tribution of the proteins and glycoproteins of influenza virus and Sendai virus. J. Virol. 6:707-716.

13. Joss, A., S. S. Gandhi, A. S. Hay, and D. C. Burke. 1969. Ribonucleic acid and protein synthesis in chick embryo cells infected with fowl plague virus. J. Virol. 4:816-822.

14. Penhoet, E., H. Miller, M. Doyle, and S. Blatti. 1971. RNAdependent RNA polymerase activity in intluenza virions. Proc. Nat. Acad. Sci. U.S.A. 68:1369-1371.

15. Pons, M. W. 1971. Isolation of influenza virus ribonucleoprotein from infected cells. Demonstration of the presence of negative-stranded RNA in viral RNP. Virology 46:149-160.

16. Pons, M. W. 1972. Studies on the replication of influenza virus RNA. Virology 47:823-832.
17. Pons, M. W., I. T. Schulze, and G. K. Hirst. 1969. Isolation and characterization of the ribonucleoprotein of influenza virus. Virology 39:250-259.

18. Schulze, I. T. 1970. The structure of influenza virus. I. The polypeptides of the virion. Virology 42:890-904.

19. Schulze, I. T. 1972. The structure of influenza virus. II. A model based on the morphology and composition of subviral particles. Virology 47:181-196.

20. Skehel, J. J. 1971. RNA-dependent RNA polymerase activity of the influenza virus. Virology 45:793-796.

21. Skehel, J. J., and G. C. Schild. 1971. The polypeptide composition of influenza A virus. Virology 44:396-408. 